\title{
Enhancement of vaccine-mediated antitumor immunity in cancer patients after depletion of regulatory $\mathrm{T}$ cells
}

\author{
Jens Dannull, ${ }^{1}$ Zhen Su, ${ }^{1}$ David Rizzieri, ${ }^{2}$ Benjamin K. Yang, ${ }^{1}$ Doris Coleman, ${ }^{1}$ Donna Yancey, ${ }^{1}$ \\ Aijing Zhang, ${ }^{1}$ Philipp Dahm,, ${ }^{1}$ Nelson Chao, ${ }^{2}$ Eli Gilboa, ${ }^{1}$ and Johannes Vieweg ${ }^{1}$ \\ ${ }^{1}$ Genitourinary Cancer Immunotherapy Program, Division of Urology, Department of Surgery, and \\ 2Division of Cellular Therapy, Department of Medicine, Duke University Medical Center, Durham, North Carolina, USA.
}

\begin{abstract}
In this study, we investigated whether elimination of $\mathrm{CD}^{+} / \mathrm{CD}^{2} 5^{+}$Tregs using the recombinant IL-2 diphtheria toxin conjugate $\mathrm{DAB}_{389} \mathrm{IL}-2$ (also known as denileukin diftitox and ONTAK) is capable of enhancing the immunostimulatory efficacy of tumor RNA-transfected DC vaccines. We show that DAB ${ }_{389} I L-2$ is capable of selectively eliminating CD25-expressing Tregs from the PBMCs of cancer patients without inducing toxicity on other cellular subsets with intermediate or low expression of CD25. DAB ${ }_{389} \mathrm{IL}-2$-mediated Treg depletion resulted in enhanced stimulation of proliferative and cytotoxic $T$ cell responses in vitro but only when $\mathrm{DAB}_{389} \mathrm{IL}-2$ was omitted during $\mathrm{T}$ cell priming. $\mathrm{DAB}_{389} \mathrm{IL}-2$ significantly reduced the number of Tregs present in the peripheral blood of metastatic renal cell carcinoma (RCC) patients and abrogated Treg-mediated immunosuppressive activity in vivo. Moreover, $\mathrm{DAB}_{389} \mathrm{IL}-2$-mediated elimination of Tregs followed by vaccination with RNA-transfected DCs significantly improved the stimulation of tumor-specific $T$ cell responses in RCC patients when compared with vaccination alone. Our findings may have implications in the design of immune-based strategies that may incorporate the Treg depletion strategy to achieve potent antitumor immunity with therapeutic impact.
\end{abstract}

\section{Introduction}

We have previously shown that vaccination with RNA-transfected DCs is an effective strategy to stimulate potent $\mathrm{T}$ cell responses in patients with metastatic cancers $(1,2)$. In this study, we investigated whether the immunostimulatory properties of RNA-transfected DC vaccines can be further enhanced by disrupting regulatory pathways that suppress the activation and function of tumor-specific T effector cells in the cancer patient. Recent research has shown that $\mathrm{CD} 4^{+} \mathrm{T}$ cells constitutively expressing the IL-2 receptor $\alpha$-chain (CD25) act in a regulatory capacity by suppressing the activation and function of other $\mathrm{T}$ cells (3). Their physiological role is to protect the host against the development of autoimmunity by regulating immune responses against antigens expressed by normal tissues $(4,5)$. Since tumor antigens are largely self antigens, Tregs may also prevent the tumor-bearing host from mounting an effective antitumor immune response. Previous studies have shown that elevated numbers of $\mathrm{CD} 4{ }^{+} \mathrm{CD} 25^{+}$Tregs can be found in advanced cancer patients (6) and that high Treg frequencies are associated with reduced survival (7). The important role of $\mathrm{CD} 4^{+} \mathrm{CD} 25^{+}$Tregs in controlling tumor growth was further highlighted by the demonstration that depletion of Tregs using anti-CD25 antibodies

Nonstandard abbreviations used: 7-AAD, 7-amino-actinomycin D; CTLA-4, CTLassociated antigen-4; $\mathrm{DAB}_{389} \mathrm{IL}-2$, recombinant IL-2 diphtheria toxin conjugate; fluM1, influenza virus matrix protein 1; FoxP3, forkhead box P3 transcriptional regulator; GITR, glucocorticoid-induced TNF receptor family gene; hTERT, human telomerase reverse transcriptase; MART-1, melanocyte antigen recognized by T cells 1; MLR, mixed-lymphocyte reaction; MTT, 3-(4,5-dimethylthiazol-2-yl)-2,5diphenyl tetrazolium bromide salt; OVA, ovarian carcinoma; RCC, renal cell carcinoma; RE, renal epithelium.

Conflict of interest: The authors have declared that no conflict of interest exists.

Citation for this article: J. Clin. Invest. 115:3623-3633 (2005).

doi:10.1172/JCI25947. can evoke effective antitumor immunity in mice $(8,9)$. Moreover, anti-CD25 therapy enhanced the therapeutic efficacy of GM-CSF-secreting B16 tumor cells and prolonged survival of tumor-bearing animals (10). Cumulatively, these experimental data suggest that the efficacy of cancer vaccination could be enhanced by treatment with agents that lead to the preferential depletion of $\mathrm{CD} 4{ }^{+} \mathrm{CD} 25^{+}$Tregs, such as compounds that target cells expressing the IL-2 receptor CD25 subunit.

In this study, we used the recombinant IL-2 diphtheria toxin conjugate $\mathrm{DAB}_{389} \mathrm{IL}-2$ (also known as denileukin diftitox and ONTAK) to eliminate CD25-expressing Tregs in metastatic renal cell carcinoma (RCC) patients. $\mathrm{DAB}_{389} \mathrm{IL}-2$ contains the catalytical and membrane translocation domain of diphtheria toxin (11). The binding domain for the diphtheria toxin receptor, however, is deleted and replaced by the human IL-2 gene, which allows for targeting of CD25-expressing cells. The cytotoxic action of $\mathrm{DAB}_{389} \mathrm{IL}-2$ occurs as a result of binding to the high-affinity IL-2 receptor, subsequent internalization, and enzymatic inhibition of protein synthesis, ultimately leading to cell death.

Here we show that $\mathrm{DAB}_{389} \mathrm{IL}-2$ is capable of selectively eliminating Tregs from human PBMCs in a dose-dependent manner without apparent bystander toxicity to other PBMCs or $\mathrm{CD}^{+} \mathrm{T}$ cells with intermediate- or low-level expression of CD25. Treg depletion resulted in enhanced stimulation of proliferative and cytotoxic $\mathrm{T}$ cell responses in vitro but only when $\mathrm{DAB}_{389} \mathrm{IL}-2$ was used prior to and omitted during the T cell priming phase. Depletion of Tregs in RCC patients followed by vaccination with tumor RNA-transfected DCs led to improved stimulation of tumor-specific T cells when compared with vaccination alone. To our knowledge, we provide the first clinical evidence that in vivo elimination of Tregs is capable of enhancing the magnitude of vaccine-mediated, tumorspecific $\mathrm{T}$ cell responses in humans. 
A
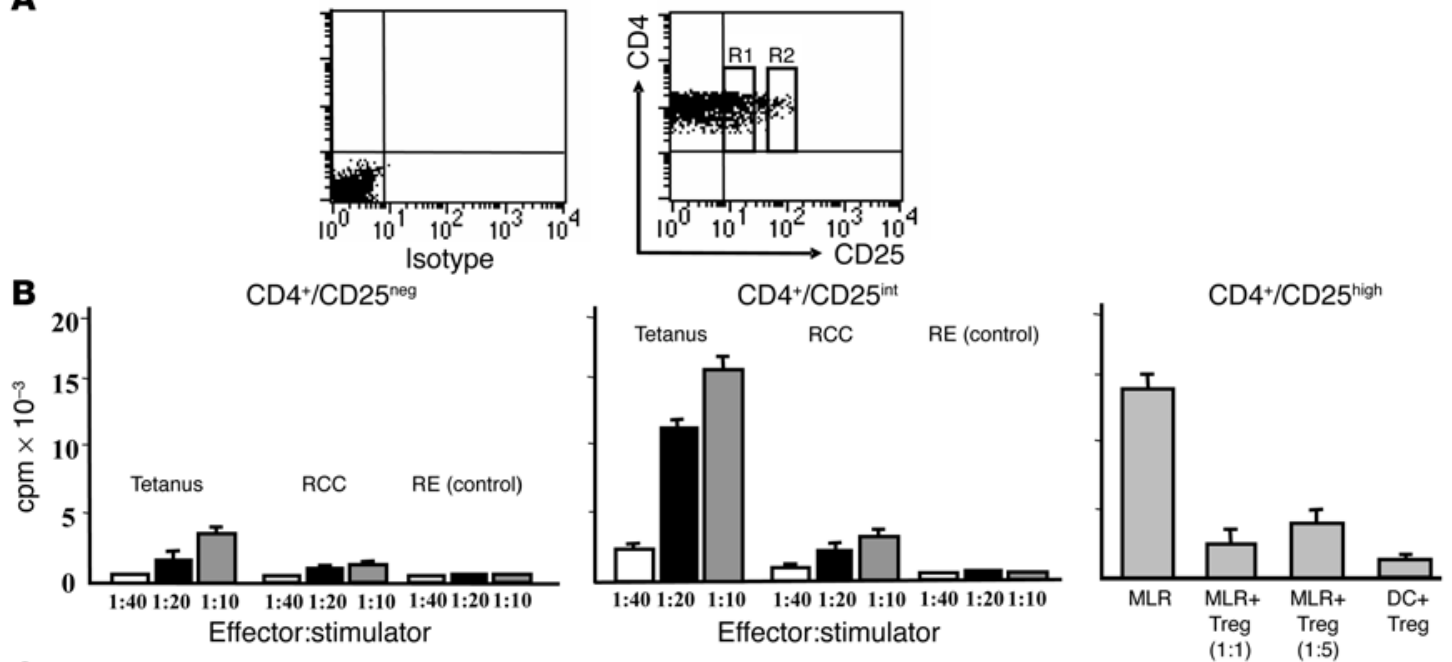

C $\mathrm{CD}^{+} / \mathrm{CD}^{2} 5^{\text {high }}$
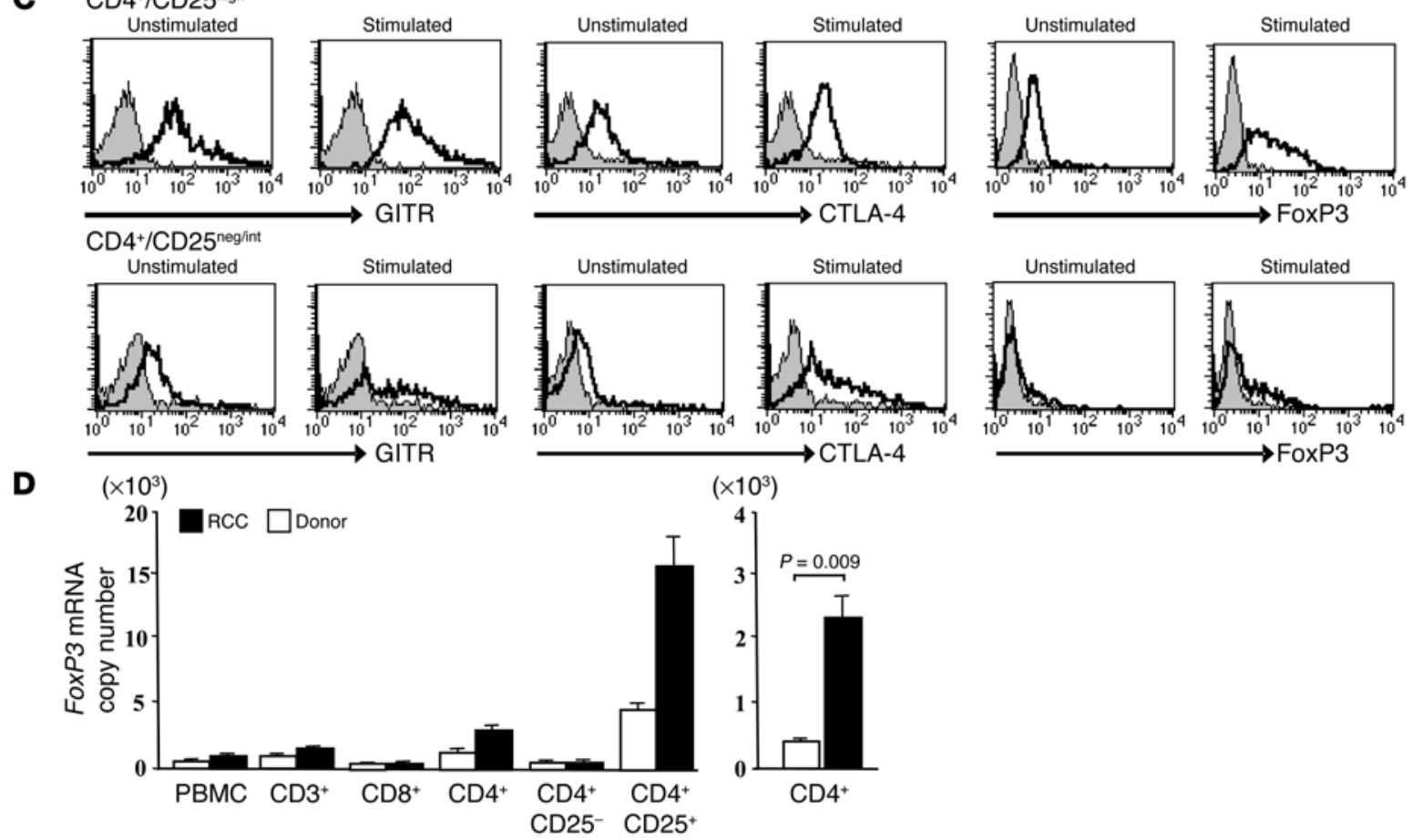

$\left(\times 10^{3}\right)$

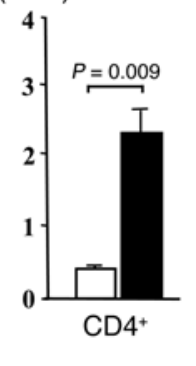

Figure 1

Characterization of CD4+ T cell subsets. (A) PBMCs from an RCC patient were stained with anti-CD4/CD25 mAbs and analyzed by FACS. (B) CD4 + CD25 neg, CD4+CD25int (R1), and CD4 + CD25 high (R2) T cells were sorted. For functional analysis, CD4+CD25 neg (left panel) and CD4+CD25int (middle panel) T cells were stimulated with tetanus toxoid-loaded DCs (tetanus), DCs transfected with autologous RCC RNA (RCC), or with DCs transfected with autologous RE RNA (RE) at the indicated stimulator to responder ratios. After 48 hours, cells were pulsed with ${ }^{3} \mathrm{H}$-thymidine, and incorporation was determined using a liquid scintillation counter. CD4 ${ }^{+} \mathrm{CD} 25^{\text {high }}$ cells (right panel) were functionally validated by MLR. Mixture ratios of $1 \mathrm{CD} 4{ }^{+} \mathrm{CD} 25^{\text {high }}$ cell per T cell (Treg 1:1) or $1 \mathrm{CD} 4^{+} \mathrm{CD} 25^{\text {high }}$ cell per $5 \mathrm{~T}$ cells (Treg 1:5) were added to the reaction, and inhibition of cell proliferation was analyzed. As a negative control, proliferation of $C D 4+C D 25^{\text {high }}$ cells was determined in the presence of allogeneic DCs only (DC+Treg). Results are presented as means with SD calculated from triplicate wells. (C) FACS-based detection of GITR, CTLA-4, and FoxP3 by CD4+CD25 neg/int and CD4 ${ }^{+}$CD25 high $T$ cells subsets with or without stimulation using anti-CD3/CD28 mAb. Gray histograms represent isotypic controls. (D) Left panel: analysis of FoxP3 transcripts was performed by real-time PCR on indicated T cell populations. FoxP3 mRNA copy numbers were normalized to $1 \times 10^{7}$ copies of $\beta$-actin mRNA. A representative result from 3 subjects is shown. Right panel: FoxP3 mRNA was amplified from CD4 ${ }^{+} T$ cells isolated from RCC patients $(n=5)$ and healthy donors $(n=5)$. Differences in FoxP3 mRNA expression among groups were significant $(P=0.009)$.

\section{Results}

Phenotypic and functional characterization of Tregs. The definition and enumeration of human Tregs is complicated by the fact that
CD25 is a marker of $\mathrm{T}$ cell activation $(12,13)$. Human $\mathrm{CD}^{+} \mathrm{T}$ cells expressing CD25 represent a heterogeneous cell population containing not only regulatory but also effector/memory 

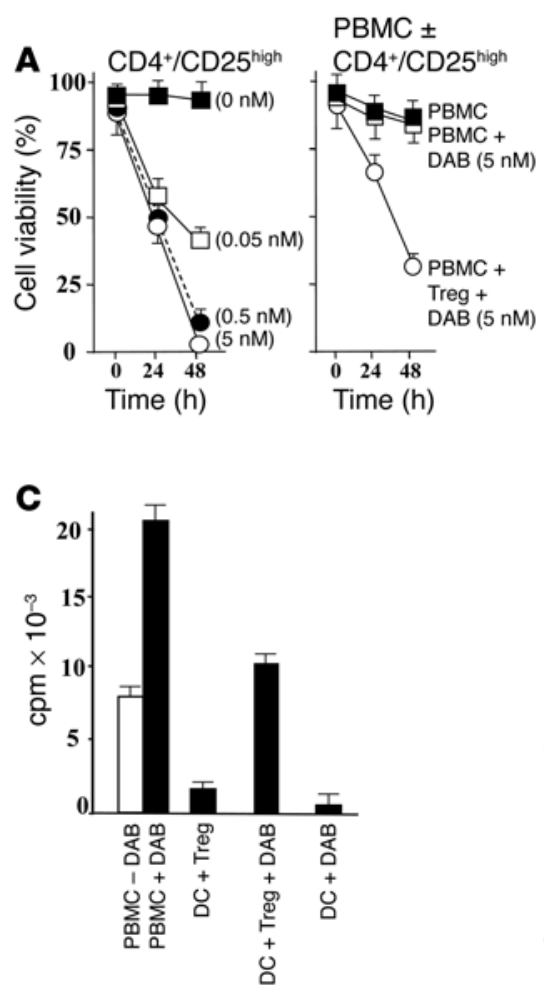

Figure 2

Enhancement of $T$ cell responses after Treg depletion. (A and $\mathbf{B}) \mathrm{CD}^{+} \mathrm{CD} 25^{\text {high }}$ cells were isolated by FACS sorting and incubated for 6 hours in the presence of increasing concentrations of $\mathrm{DAB}_{389} \mathrm{lL}-2$ (left panel). In order to determine $\mathrm{DAB}_{389} \mathrm{IL}-2-$ mediated toxicity, PBMCs and PBMCs admixed with $\mathrm{CD}^{+} / \mathrm{CD} 25^{\text {high }}$ cells at a 1:1 ratio were incubated with or without $\mathrm{DAB}_{389 \mathrm{l}} \mathrm{L}-2(5 \mathrm{nM})$ for 6 hours. In all experiments, cell viability was determined through MTT assays (A) or 7-AAD staining (B). Representative results from 3 evaluable subjects are presented. (C) Treg-depleted PBMCs (PBMC+DAB) or nondepleted PBMCs (PBMC-DAB) from an RCC patient were analyzed in allogeneic MLRs using DCs at a responder to stimulator ratio of 20:1. Cell proliferation was significantly inhibited when isolated CD4+/CD25 high cells were added to PBMCs at a 1:1 PBMC/ CD $4{ }^{+}$CD25 $5^{\text {high }}$ cell ratio $(D C+$ Treg). This inhibition was reversible when the added CD4+/CD25 high cells were pretreated with $\mathrm{DAB}_{389} \mathrm{IL}-2(5 \mathrm{nM})$ for 48 hours (DC+Treg+DAB). Exposure of PBMCs to $\mathrm{DAB}_{389 \mathrm{l}} \mathrm{L}-2$ during the $\mathrm{T}$ cell-priming phase (day 2 ) led to complete inhibition of $\mathrm{T}$ cell proliferation (DC+DAB). (D) DCs transfected with mRNA encoding $h T E R T$ or MART-1 were used to stimulate CTL from Treg-depleted (filled symbols) or nondepleted (open symbols) human PBMCs.In addition, DCs loaded with MART-1-derived peptide 26-35 ELAGIGILTV (MART-1 pep) were used as stimulators. Following 2 stimulation cycles, CTLs were analyzed for their capacity to lyse their cognate (squares) or control targets (circles). As control targets, DCs loaded with GFP mRNA (mock transfected) or irrelevant peptide were used.

$\mathrm{T}$ cells (14). Analysis of PBMCs from healthy donors and RCC patients revealed the presence of $\mathrm{CD} 4^{+} \mathrm{T}$ cell populations that express increasing levels of CD25 (14). As shown in Figure 1A, 1 major subset of $\mathrm{CD} 4^{+} \mathrm{T}$ cells, isolated from the PBMCs of an RCC patient, lacked CD25 expression while a second population was characterized by intermediate levels of $\mathrm{CD} 25$, and a third, albeit small portion, exhibited high CD25 cell surface expression levels. To further characterize these 3 subsets, $\mathrm{CD}^{+} / \mathrm{CD} 25^{\text {neg, }}$, $\mathrm{CD}^{+} / \mathrm{CD} 25^{\text {int }}$, and $\mathrm{CD} 4^{+} / \mathrm{CD} 25^{\text {high }} \mathrm{T}$ cells were isolated from the PBMCs of RCC patients by FACS and functionally analyzed in vitro (Figure $1 \mathrm{~B}$ ). $\mathrm{CD} 4^{+} / \mathrm{CD} 25^{\text {neg }}$ cells expressed cell surface markers characteristic of naive/resting $\mathrm{T}$ cells and demonstrated reduced proliferative activity following exposure to tetanus toxoid, renal tumor RNA, benign renal epithelium (RE) RNA, and PBMC RNAloaded DCs. In contrast, $\mathrm{CD} 4^{+} / \mathrm{CD} 25^{\text {int }}$ cells produced a strong proliferative response against tetanus toxoid, and a significant, albeit weaker, response, against RCC RNA-encoded antigens. No proliferative response against $\mathrm{RE}$ RNA- or PBMC RNA-transfected DCs (latter not shown) was observed. $\mathrm{CD}^{+} /$ CD25 high Tregs exhibited profound immunosuppressive activity in vitro, as evidenced by inhibition of allogeneic DC-stimulated mixed-lymphocyte reaction (MLR) cultures. The addition of increasing numbers of $\mathrm{CD}^{+} / \mathrm{CD} 25^{\text {high }}$ cells (1:5 responder cells; $1: 1$ responder cells) to MLRs led to a dose-dependent inhibition of responder $\mathrm{T}$ cell proliferation while $\mathrm{CD} 4^{+} / \mathrm{CD} 25^{\text {high }} \mathrm{T}$ cells did not proliferate significantly upon stimulation with DCs (DC+Treg). Tregs demonstrated strong cell surface expression of glucocorticoid-induced TNF receptor family gene (GITR) as well as intracellular CTL-associated antigen-4 (CTLA-4) and forkhead box P3 transcriptional regulator (FoxP3) (Figure 1C). Stimulation of $\mathrm{CD} 4^{+} / \mathrm{CD} 25^{\text {high }} \mathrm{T}$ cells using anti-CD3/ CD28 antibodies resulted in enhanced expression of GITR, CTLA-4, and FoxP3 while $\mathrm{CD} 4^{+} \mathrm{T}$ cells with negative or intermediate levels of CD25 exhibited significantly lower levels of these markers after nonspecific stimulation.

Since CD25 is not an optimal marker to enumerate Tregs in human subjects, as it is upregulated upon $\mathrm{T}$ cell activation, the number of FoxP3 transcripts was determined in various $T$ cell populations using quantitative real-time PCR. FoxP3 is the most specific Treg marker currently available while other molecules expressed by Tregs (i.e., CD45RB, CD38, and CD62L) previously failed to demonstrate specificity for detecting Tregs with immunosuppressive activity $(15,16)$. To determine the specificity of FoxP3 for $\mathrm{CD} 4^{+} / \mathrm{CD} 25^{+}$ Tregs, $\mathrm{CD}^{+}, \mathrm{CD}^{+}, \mathrm{CD}^{+}, \mathrm{CD}^{+} / \mathrm{CD} 25^{-}$, and $\mathrm{CD} 4^{+} / \mathrm{CD} 25^{+} \mathrm{T}$ cells were isolated from the PBMCs of healthy volunteers and from RCC patients by magnetic bead separation, and copy numbers of FoxP3 mRNA were analyzed. Consistent with other reports $(7,17)$, high expression of FoxP3 protein (Figure 1C) and message (Figure 1D) were observed in $\mathrm{CD}^{+} / \mathrm{CD} 25^{+} \mathrm{T}$ cells while $\mathrm{CD}^{+} / \mathrm{CD} 25^{-}$and all other $\mathrm{T}$ cell subsets exhibited only low or background levels of FoxP3 mRNA (Figure 1D, left panel). When corrected for cell population frequencies, $\mathrm{CD} 4^{+} / \mathrm{CD} 25^{+}$ $\mathrm{T}$ cells contributed $64 \%$ of FoxP3 transcripts in the PBMC pool of healthy volunteers ( $84 \%$ in RCC patients) while $\mathrm{CD} 4^{+} / \mathrm{CD} 25^{-}$ cells accounted for $25 \%$ (14\% in RCC patients). Less than $10 \%$ 


\section{Table 1}

Patient characteristics and treatment assignments

\begin{tabular}{|c|c|c|c|c|c|c|c|c|c|c|c|c|c|c|c|}
\hline Subject ${ }^{A}$ & $\begin{array}{l}\text { Age } \\
\text { (yr) }\end{array}$ & Sex & $\begin{array}{l}\text { KPS } \\
(\%)\end{array}$ & Diagnosis & Metastases & $s^{B}$ Treatments $^{C}$ & $\begin{array}{c}\text { DAB } \\
\text { dose }^{D} \\
(\mu g)\end{array}$ & $\begin{array}{l}\text { No. of } \\
\text { Tregs } \\
(\% \text { CD4 }\end{array}$ & $\begin{array}{c}\text { Treg } \\
\text { depletion } \\
\begin{array}{c}(\%) \\
\text { ) }\end{array}\end{array}$ & $\begin{array}{l}\text { ELISPOTE } \\
\text { CD8+CD4+ }\end{array}$ & $\begin{array}{c}\text { Diptheria } \\
\text { titer }\end{array}$ & $\begin{array}{c}\text { Time in } \\
\text { Dx }\end{array}$ & $\begin{array}{c}\text { terva } \\
\mathrm{Nx}\end{array}$ & $\begin{array}{l}\mathrm{s}(\mathrm{mo})^{\mathrm{F}} \\
\mathrm{FU}\end{array}$ & Status \\
\hline 01-RCC-DAB & 58 & M & 80 & $\mathrm{RCC}$ & LN/BN & $\mathrm{Nx} / \mathrm{MR}$ & 2412 & 4.6 & 74 & 16.27 .6 & $1: 6561$ & 36 & 36 & 24 & AWD \\
\hline 02-RCC-DAB & 54 & $\mathrm{M}$ & 90 & $\mathrm{RCC}$ & BN $N$ & Nx/MR/Cyt/Ch/XRT & [ 1494 & 2.5 & 72 & $12.5 \quad 6.3$ & $1: 243$ & 39 & 39 & 21 & AWD \\
\hline 03-RCC-DAB & 69 & $\mathrm{~F}$ & 90 & RCC & PN & Nx/MR & 1590 & 3.7 & 68 & $\begin{array}{ll}5.4 & 2.2\end{array}$ & Neg & 3 & 2 & 1 & DOD \\
\hline 04-RCC-DAB & 60 & M & 90 & $\mathrm{RCC}$ & PN & Nx/Cyt/Ch/MR & 1906 & 3.8 & 76 & $\begin{array}{ll}7.4 & 9.7\end{array}$ & $\mathrm{Neg}$ & 170 & 204 & 5 & AWD \\
\hline 05-RCC-DAB & 57 & $\mathrm{M}$ & 100 & $\mathrm{RCC}$ & ST/PN & Nx/MR & 1566 & 2.8 & 57 & 7.831 .0 & $\mathrm{~N} / \mathrm{D}$ & 8 & 155 & 5 & AWD \\
\hline 06-RCC-DAB & 61 & $\mathrm{M}$ & 90 & $\mathrm{RCC}$ & BN & Nx/XRT/Cyt/MR & 1301 & 4.2 & 26 & $8.0 \quad 6.8$ & Neg & 14 & 26 & 6 & AWD \\
\hline 07-OVA-DABG & 56 & $\mathrm{~F}$ & 90 & OVA & ST & $\mathrm{TAH} / \mathrm{Ch} / \mathrm{MR} / \mathrm{Cyt}$ & 900 & 3.7 & 35 & 7.8 & $1: 19683$ & 35 & NA & 16 & AWD \\
\hline 08-RCC & 60 & $\mathrm{M}$ & 70 & $\mathrm{RCC}$ & LN/BN & Nx/MR/Cyt & NA & 2.7 & NA & 1.0 & ND & 10 & 10 & 8 & DOD \\
\hline 09-RCC & 61 & $\mathrm{M}$ & 75 & RCC & PN & $\mathrm{Nx} / \mathrm{MR}$ & NA & 3.2 & NA & 2.0 & $\mathrm{~N} / \mathrm{D}$ & 5 & 5 & 3 & DOD \\
\hline 10-RCC & 67 & $M$ & 85 & $\mathrm{RCC}$ & PN/ST & Nx/Cyt/MR & NA & 3.0 & NA & 3.2 & ND & 16 & 16 & 11 & AWD \\
\hline $11-\mathrm{RCC}$ & 67 & $\mathrm{M}$ & 95 & $\mathrm{RCC}$ & PN & Nx/Cyt/MR & NA & 4.4 & NA & 2.12 .0 & ND & 8 & 9 & 9 & AWD \\
\hline
\end{tabular}

Vaccine, tumor RNA-transfected DC. AIn subject identification numbers, DAB indicates pretreatment with DAB $389 \mathrm{IL}-24$ days prior to DC vaccination, RCC indicates metastatic RCC, and OVA indicates metastatic ovarian carcinoma. ${ }^{\mathrm{B} A t}$ time of study entry. ${ }^{\mathrm{C} P r i o r}$ to vaccination. ${ }^{\mathrm{D}} 18 \mu \mathrm{g} / \mathrm{kg}$. ${ }^{\mathrm{E}} \mathrm{Fold}$ increase after vaccination. FDx, time between first diagnosis of metastatic disease and first DC vaccination; Nx, time between nephrectomy and first DC vaccination; FU, time interval between last vaccination and last clinical/radiological follow-up. GSubject with ovarian carcinoma, not included in statistical analysis. AWD, alive with disease; BN, bony; Ch, chemotherapy (5-fluorouracil), Cyt, cytokines; DOD, dead of disease; KPS, Karnofsky performance status; MR, metastatic tumor resection; ND, not determined; Neg, negative; Nx, nephrectomy; PN, pulmonary nodule; ST, soft tissue; TAH, total abdominal hysterectomy; XRT, radiation therapy.

of FoxP3 transcripts were expressed by $\mathrm{CD}^{+} \mathrm{T}$ cells and $\mathrm{CD}^{-}$ cells (B cells, monocytes/macrophages, and NK cells; data not shown). When assayed by FACS, $\mathrm{CD}^{+} / \mathrm{CD} 25^{\text {high }} / \mathrm{FoxP}^{+}$Treg frequencies detected in the peripheral blood of metastatic RCC patients after tumor nephrectomy $(n=10)$ ranged from $2.5 \%$ to $4.6 \%$ and were significantly elevated $(2.1 \pm 1.2$-fold increase) when compared with healthy volunteer controls $(n=10)$. Accordingly, there was a statistically significant increase in the number of FoxP3 transcripts that could be amplified from isolated CD $4^{+}$ $\mathrm{T}$ cells of RCC patients when compared with those of healthy volunteers $(P=0.009)$ (Figure $1 \mathrm{D}$, right panel).

In summary, we show that $\mathrm{CD}^{+} / \mathrm{CD} 25^{\text {high }} \mathrm{T}$ cells isolated from the PBMCs of RCC patients exhibited suppressive activity while $\mathrm{CD} 4{ }^{+}$cells with negative or intermediate CD25 levels represented either naive/resting or memory/effector T cells. Therefore, in clinical settings, it will be important to identify suitable reagents that allow selective elimination of CD25 $5^{\text {high }}$ Tregs while sparing other cells expressing low or intermediate levels of CD25. Consistent with other reports $(7,18)$, higher Treg frequencies were measured in the peripheral blood of metastatic RCC patients when compared with healthy donor controls.

Selective elimination of Tregs in vitro. Human malignant cells overexpressing CD25 can be inactivated or eliminated using the recombinant IL-2 diphtheria toxin conjugate, denileukin difititox $\left(\mathrm{DAB}_{389} \mathrm{IL}-2\right)(19)$. In order to determine whether $\mathrm{DAB}_{389} \mathrm{IL}-2$ could serve as a suitable reagent to achieve Treg depletion under clinically relevant conditions, we analyzed Treg susceptibility to $\mathrm{DAB}_{389}$ IL-2 in 3-(4,5-dimethylthiazol-2-yl)-2,5-diphenyl tetrazolium bromide salt (MTT) assays. In these experiments, we chose conditions that resembled the pharmacokinetics of a single intravenous dose of $\mathrm{DAB}_{389} \mathrm{IL}-2(18 \mu \mathrm{g} / \mathrm{kg})$ corresponding to $5 \mathrm{nM}$ peak plasma concentrations. In previous clinical trials, this dose level demonstrated optimal clinical efficacy and acceptable toxicity profiles (20). Given a plasma half-life of approximately 60 minutes and a dissociation constant of $1 \mathrm{pM}$ for $\mathrm{DAB}_{389} \mathrm{IL}-2$ and the high-affinity IL-2 receptor, $\mathrm{DAB}_{389} \mathrm{IL}-2$ plasma levels were projected to reach suboptimal concentrations after 6 hours. Therefore, in the experiments shown in Figure 2A, the viability of isolated $\mathrm{CD}^{+} / \mathrm{CD} 25^{\text {high }} \mathrm{T}$ cells was analyzed after a 6-hour exposure to increasing concentrations of $\mathrm{DAB}_{389} \mathrm{IL}-2$ (range $0.05-5.0 \mathrm{nM}$ ) in vitro over 48 hours. For $\mathrm{CD} 4^{+} / \mathrm{CD} 25^{\text {high }}$ Tregs, a significant reduction in cell viability was observed 24 hours after exposure to $\mathrm{DAB}_{389} \mathrm{IL}_{\mathrm{L}} 2$. Efficient killing of $\mathrm{CD}^{+} /$ CD25 high cells was noted at $0.5 \mathrm{nM}$ concentrations after 48 hours while complete depletion was achieved at a $5 \mathrm{nM}$ concentration. In contrast, exposure of $\mathrm{CD}^{+} / \mathrm{CD} 25^{\text {neg }}$ and $\mathrm{CD} 4^{+} /$ CD25 int cells to $\mathrm{DAB}_{389} \mathrm{IL}-2$ did not result in significant cell death except when these cells were exposed to $\mathrm{DAB}_{389} \mathrm{IL}-2$ concentrations higher than $10 \mathrm{nM}$ (latter not shown). In another set of experiments, $\mathrm{DAB}_{389} \mathrm{IL}-2$ used at a $5 \mathrm{nM}$ concentration resulted in specific killing of Tregs but not of other bystander cells in vitro. As shown in Figure $2 \mathrm{~A}$, there were no significant differences in PBMC viability over time when $\mathrm{DAB}_{389} \mathrm{IL}-2(5 \mathrm{nM})$ was added to the culture. In contrast, when PBMCs and Tregs were mixed (1:1 ratio), cell viability was reduced by more than $60 \%$ after 48 hours, suggesting selective, diphtheria toxin-mediated Treg killing without bystander toxicity. In order to corroborate these findings, 7-amino-actinomycin D (7-AAD) staining was performed on $\mathrm{CD}^{+} \mathrm{T}$ cell populations with increasing densities of CD25 (Figure 2B). Consistent with the experiments shown in Figure $2 \mathrm{~A}$, optimal killing of $\mathrm{CD} 4^{+} / \mathrm{CD} 25^{\text {high }}$ Tregs was achieved using 5-nM DAB ${ }_{389} \mathrm{IL}-2$ concentrations while $\mathrm{DAB}_{389} \mathrm{IL}-2$ exposure to other $\mathrm{CD}^{+} \mathrm{T}$ cells with lower or no CD25 expression revealed only background levels of $7-A A D$ staining.

Next, the impact of $\mathrm{DAB}_{389} \mathrm{IL}-2$ on freshly activated lymphocytes was analyzed after stimulation with allogeneic DCs in MLR cultures. $\mathrm{DAB}_{389} \mathrm{IL}-2$-mediated Treg depletion prior to initiation of MLR culture resulted in a 2 -fold increase in proliferation of responder cells $(\mathrm{PBMC} \pm \mathrm{DAB})$. Conversely, the addition of isolated Tregs (DC+Treg) resulted in an 
A

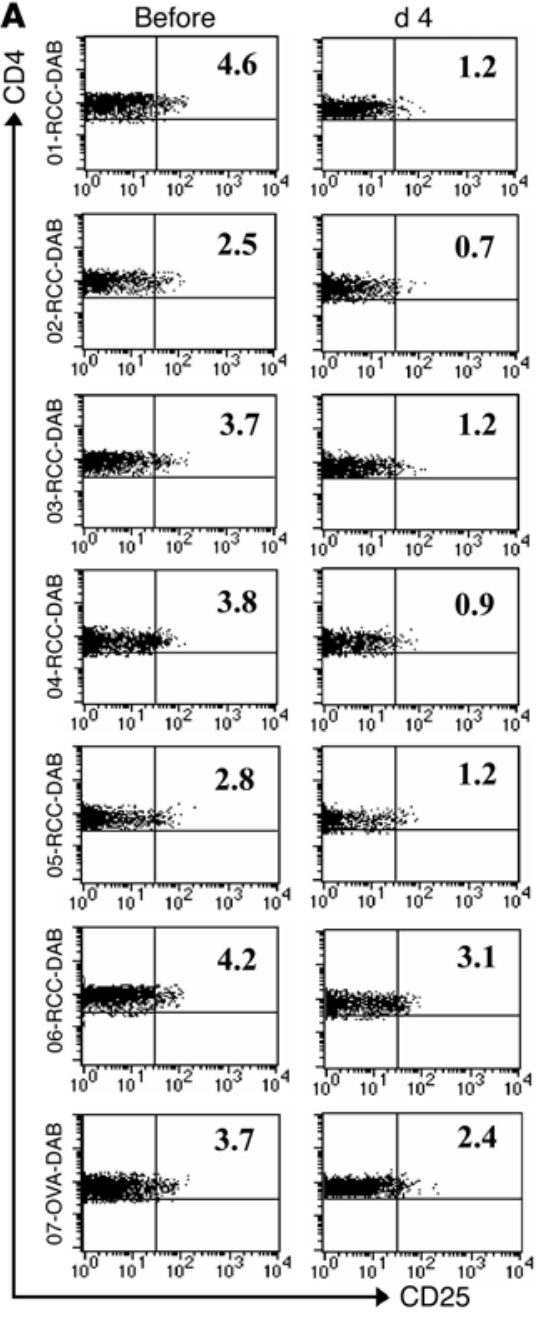

B
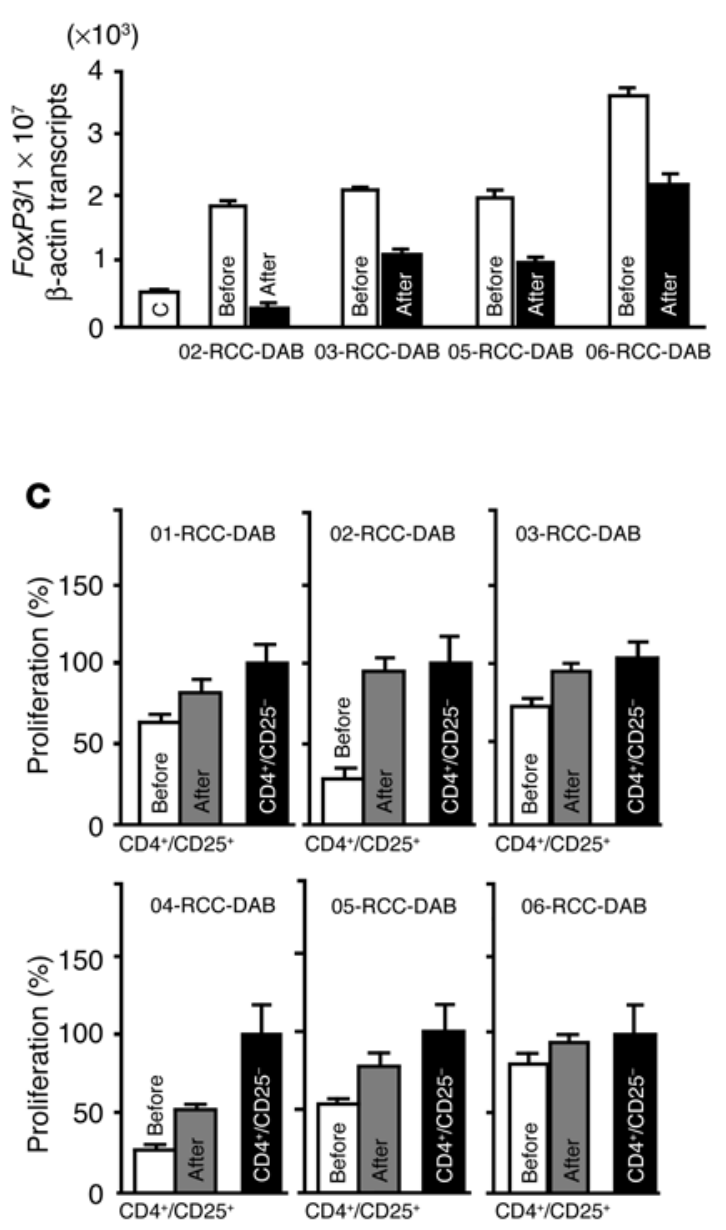

Figure 3

Depletion of Tregs in study subjects. (A) $\mathrm{CD}_{4}{ }^{+} \mathrm{T}$ cells isolated from all $\mathrm{DAB}_{389}$ IL-2-treated study patients were analyzed by flow cytometry for expression of CD25 prior to and 4 days after intravenous administration; percentages of $\mathrm{CD}^{+} / \mathrm{CD} 25^{\text {high }}$ $T$ cells are shown. (B) Reduction of FoxP3 mRNA copy numbers before and after $\mathrm{DAB}_{389} \mathrm{IL}-2$ treatment was determined by $\mathrm{CD} 4{ }^{+} \mathrm{T}$ cells derived from 4 study subjects, as described in the legend to Figure 1D. The average FoxP3 mRNA copy number averaged from 5 healthy volunteers was used as control (C). (C) Functional analysis of Tregs isolated from study subjects prior to and after $\mathrm{DAB}_{386} \mathrm{~L} \mathrm{~L}-2$ administration. $\mathrm{CD}^{+} / \mathrm{CD}^{2} 5^{+}$and $\mathrm{CD} 4{ }^{+} / \mathrm{CD} 25^{-} \mathrm{T}$ cell subsets were isolated from PBMC samples by magnetic bead separation, and Treg-mediated inhibition of activated $\mathrm{CD}^{+} / \mathrm{CD} 25^{-}$indicator $\mathrm{T}$ cells was measured according to a protocol described previously (28). approximately $80 \%$ reduction in T cell proliferation (1:1 Treg/ responder ratio) (Figure $2 \mathrm{C}$ ). Preincubation of Tregs with 5-nM $\mathrm{DAB}_{389} \mathrm{IL}-2$ (DC+Treg+DAB) significantly abrogated their inhibitory effect when added to MLR; however, responder cells did not proliferate as vigorously as in the absence of Tregs, suggesting potential contact inhibition by Tregs, as reported previously (21). Importantly, the addition of $\mathrm{DAB}_{389} \mathrm{IL}-2$ two days after initiation of MLR (DC+DAB) completely abrogated the proliferation of responder cells, suggesting that $\mathrm{DAB}_{389}$ IL-2 eliminated not only Tregs but also freshly activated naive $T$ cells that acquired CD25 expression.

These experiments suggest that $\mathrm{DAB}_{389} \mathrm{IL}-2$ is a suitable reagent for selectively eliminating Tregs in vitro without affecting other lymphocytes, including naive and memory $\mathrm{T}$ cells with negative or intermediate expression levels of CD25, respectively. Our data further indicate that in a vaccination setting, $\mathrm{DAB}_{389} \mathrm{IL}-2$ should only be applied prior to immunization but not during the vaccination phase, since activated effector $T$ cells appear susceptible to $\mathrm{DAB}_{389} \mathrm{IL}-2$-mediated toxicity.

Enhancement of $T$ cell responses after Treg depletion in vitro. To provide evidence that $\mathrm{DAB}_{389} \mathrm{IL}-2$-mediated Treg depletion is capable of augmenting antigen-specific $T$ cell responses in vitro, CTLs were stimulated from PBMCs that were pretreated with or without $\mathrm{DAB}_{389} \mathrm{IL}-2(5 \mathrm{nM})$ (Figure 2D). PBMCs were stimulated twice with autologous DCs transfected with human telomerase reverse transcriptase ( $D T E R T$ ) and melanocyte antigen recognized by $\mathrm{T}$ cells 1 (MART-1) mRNA. In addition, DCs pulsed with an HLA-A0201-restricted MART-1 peptide were used as stimulators. RNA-transfected DCs were not only used as stimulators but also served as specific or control targets, as described previously (2, 22-24). The ability of the stimulated, antigen-specific CTLs to recognize their cognate but not control target cells was analyzed in standard cytotoxicity assays. As shown in Figure 2D, CTLs stimulated from Treg-depleted PBMCs exhibited significantly higher lytic activity against antigens encoded by $b T E R T$ or MART-1 mRNA than CTLs stimulated from nondepleted PBMCs. In contrast, only modest, statistically insignificant improvement of antigen-specific killing was observed when MART-1 peptidepulsed DCs were used as stimulators.

These data suggest that depletion of Tregs from human PBMCs enhances the stimulation of antigen-specific CTLs in vitro. It appears that among other factors, the impact of this strategy is influenced by the strength of the antigenic signal (25), as evidenced by the fact that $\mathrm{T}$ cell responses against mRNA-encoded self antigens was significantly enhanced. In contrast, the Tregdepletion strategy was less effective in improving CTL responses when DCs presenting high densities of peptide-MHC complexes (peptide pulsing) were used for stimulation. 
A
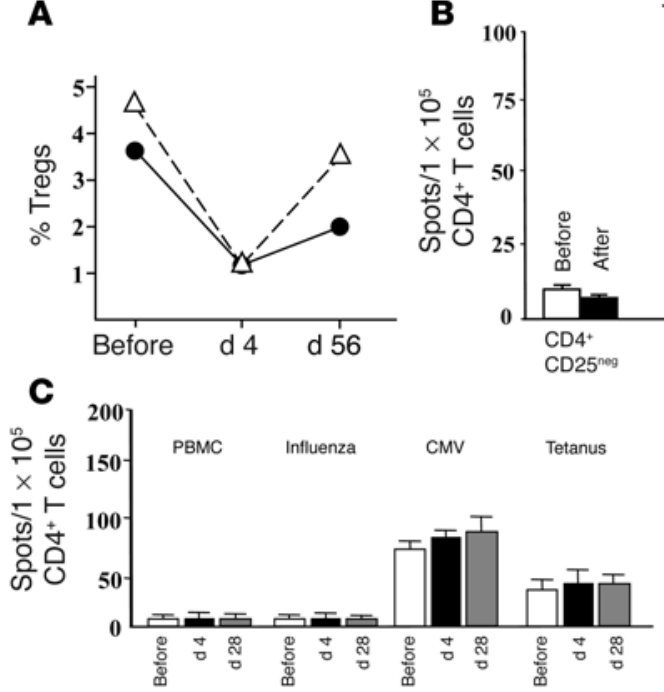

$\mathbf{E}$

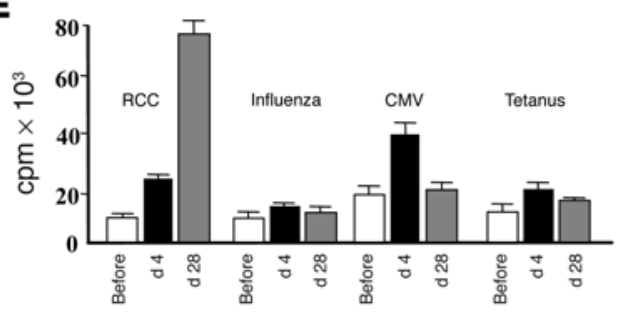

B
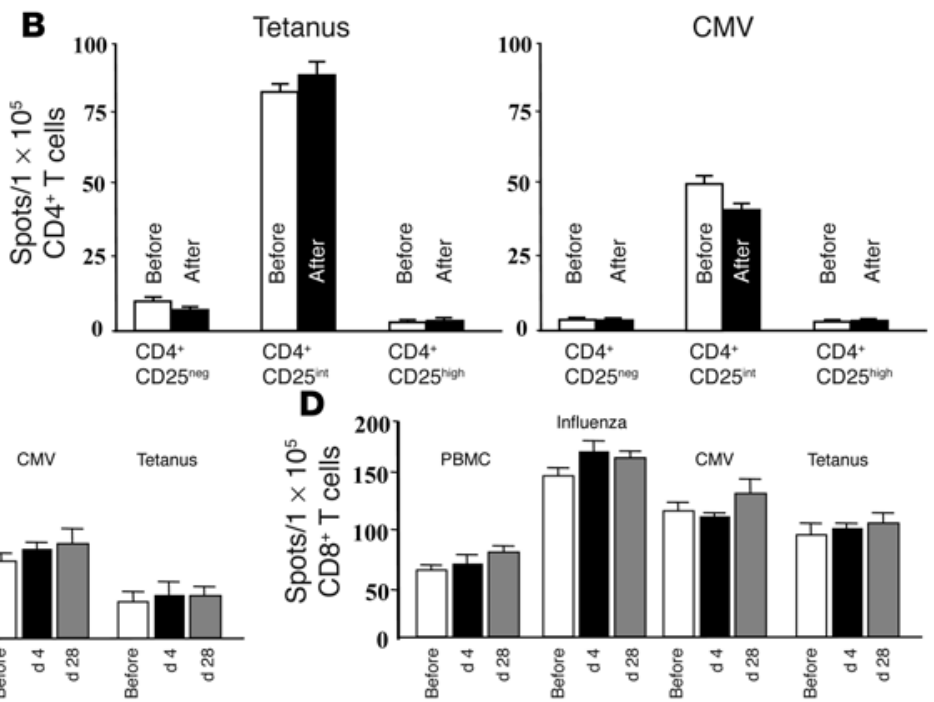

Figure 4

Specificity of Treg depletion. (A) Calculated CD4+/CD25 high Treg frequencies in 2 study subjects (01-RCCDAB; 03-RCC-DAB) prior to, 4 days after, and 2 weeks after final vaccination (study week 8; d 56). (B) IFN- $\gamma$ ELISPOT were performed on sorted $\mathrm{CD} 4{ }^{+} \mathrm{CD} 25^{\text {neg, }} \mathrm{CD} 4{ }^{+} \mathrm{CD} 25^{\text {int, }}$ and $\mathrm{CD} 4{ }^{+} \mathrm{CD} 25^{\text {high }} \mathrm{T}$ cell subsets using tetanus toxoid and CMV lysate-pulsed DCs as stimulators. (C-E) In separate experiments, IFN- $\gamma$ ELISPOT and antigen-specific proliferation analyses were performed on T cells isolated prior to vaccination and 4 and 28 days after $\mathrm{DAB}_{389} \mathrm{IL}-2$ treatment (results from patient RCC-01-DAB). For ELISPOT assays, $1 \times 10^{5}$ purified $\mathrm{CD} 4^{+} \mathrm{T}$ cells $(\mathbf{C})$ or $1 \times 10^{5}$ purified CD8+ T cells (D) were stimulated with $1 \times 10^{4}$ DCs that were transfected with fluM1 mRNA, autologous PBMC RNA, CMV lysate $(20 \mu \mathrm{g} / \mathrm{ml})$, or tetanus toxoid $(0.5 \mu \mathrm{g} / \mathrm{ml})$. After 18 hours, visible spots were enumerated using an automated ELISPOT reader. The same stimulators and RCC RNA-transfected $\mathrm{DC}$ s were used in proliferation assays $(\mathbf{E})$. For proliferation assays, isolated $\mathrm{CD} 3^{+} \mathrm{T}$ cells were used as responders. Assays were performed at a stimulator/responder ratio of 1:10. After 4 days, cells were pulsed with $1 \mu \mathrm{Ci}$ of ${ }^{3} \mathrm{H}$-thymidine, and incorporated radioactivity was determined after 16 hours by liquid scintillation counting.

Depletion of Tregs in vivo. Having shown that Treg elimination is capable of enhancing $\mathrm{T}$ cell responses in vitro, a clinical study was initiated to test the Treg-depletion concept in a human vaccination setting. A total of 11 patients, including 10 with metastatic RCC and 1 with disseminated ovarian carcinoma (OVA), were treated in a study approved by the Duke University Institutional Review Board and the FDA. Seven subjects received a single intravenous dose of $\mathrm{DAB}_{389} \mathrm{IL}-2(18 \mu \mathrm{g} / \mathrm{kg}) 4$ days prior to vaccination with tumor RNA-transfected DCs while a second cohort of 4 subjects was treated with the vaccine alone (Table 1 ). Outside the study, PBMCs were obtained from 1 additional RCC subject who received a single dose of $\mathrm{DAB}_{389} \mathrm{IL}-2(18 \mu \mathrm{g} / \mathrm{kg})$ but no vaccine. Consistent with reports of others, $\mathrm{DAB}_{389} \mathrm{IL}-2$-related toxicities included grade I constitutional symptoms such as low-grade fever and malaise $(n=4)$, grade I elevation of serum rheumatoid factor $(n=1)$, and transient grade II serum alanine aminotransferase (ALT) elevations $(n=1)$ (11). RNA-transfected DC injections were well tolerated without any major clinical toxicities or serologic/ immunologic evidence of autoimmunity $(2,26)$.
In order to quantify the presence of $\mathrm{CD} 4^{+} / \mathrm{CD} 25^{\text {neg }}$, $\mathrm{CD}^{+} / \mathrm{CD} 25^{\text {int }}$, and $\mathrm{CD}^{+} /$ $\mathrm{CD} 25^{\text {high }} \mathrm{T}$ cells in PBMC samples collected prior to and after $\mathrm{DAB}_{389} \mathrm{IL}-2$ treatment, flow cytometry was performed on patientderived PBMC samples (Figure $3 \mathrm{~A})$. Gates were set on $\mathrm{CD} 4^{+} / \mathrm{CD} 25^{\text {high }} \mathrm{T}$ cells that constitutively expressed FoxP3 protein, as shown in Figure 1C. In all 7 subjects analyzed, $\mathrm{DAB}_{389} \mathrm{IL}-2$ administration resulted in significant reduction (range $26 \%$ to $76 \%$ ) of $\mathrm{CD} 4^{+} / \mathrm{CD} 25^{\text {high }}$ Tregs 4 days following intravenous infusion. Additional evidence that Tregs were depleted and that $\mathrm{CD} 25^{\text {neg/int }} \mathrm{T}$ cell subsets were unaffected was provided by the observation that the number of total CD25 pos cells measured in each patient after $\mathrm{DAB}_{389} \mathrm{IL}-2$ administration decreased correspondingly with the number of depleted $\mathrm{CD}^{+} / \mathrm{CD} 25^{\text {high }}$ Tregs (data not shown). Moreover, as shown in 4 RCC patients from whom sufficient cells were available for analysis (02-RCC-DAB，03-RCCDAB, 05-RCC-DAB, and 06-RCC-DAB), DAB ${ }_{389} \mathrm{IL}-2$ treatment resulted in a significant reduction of FoxP3 transcripts after $\mathrm{DAB}_{389} \mathrm{IL}-2$ treatment, as determined by quantitative real-time PCR (Figure 3B). In these subjects, FoxP3 mRNA copy numbers (normalized to $\beta$-actin transcripts) were reduced by approximately $30 \%$ to $80 \%$ within purified blood $C D 4^{+}$cells 4 days after $\mathrm{DAB}_{389} \mathrm{IL}-2$ administration. Finally, $\mathrm{CD}^{+} / \mathrm{CD} 25^{+} \mathrm{T}$ cells isolated prior to but not 4 days after $\mathrm{DAB}_{386} \mathrm{IL}-2$ treatment consistently inhibited anti-CD3/CD28-mediated activation of $\mathrm{CD}^{+} /$ CD25- indicator T cells in all RCC subjects analyzed (Figure 3C), suggesting abrogation of Treg-mediated immunosuppressive activity in vivo. Notably, DAB ${ }_{389}$ IL-2-mediated Treg elimination was transient, since approximately $75 \%$ of Tregs were restored within 2 months in the patients' peripheral $\mathrm{T}$ cell pool (Figure 4A).

In 5 of 6 evaluable $\mathrm{DAB}_{389}$ IL-2-treated subjects, minor reductions (averaging 10\%) in absolute neutrophil counts were observed while 1 subject exhibited a decrease of $20 \%$. Accordingly, among these 5 with only minor absolute neutrophil count reductions, there were no significant changes in the relative number of $\mathrm{CD}^{+}$, $\mathrm{CD}^{+}$, and $\mathrm{CD}^{+} \mathrm{T}$ cells, $\mathrm{B}$ cells, monocytes/macrophages (CD14), and NK cells after treatment. In order to address the concern that 

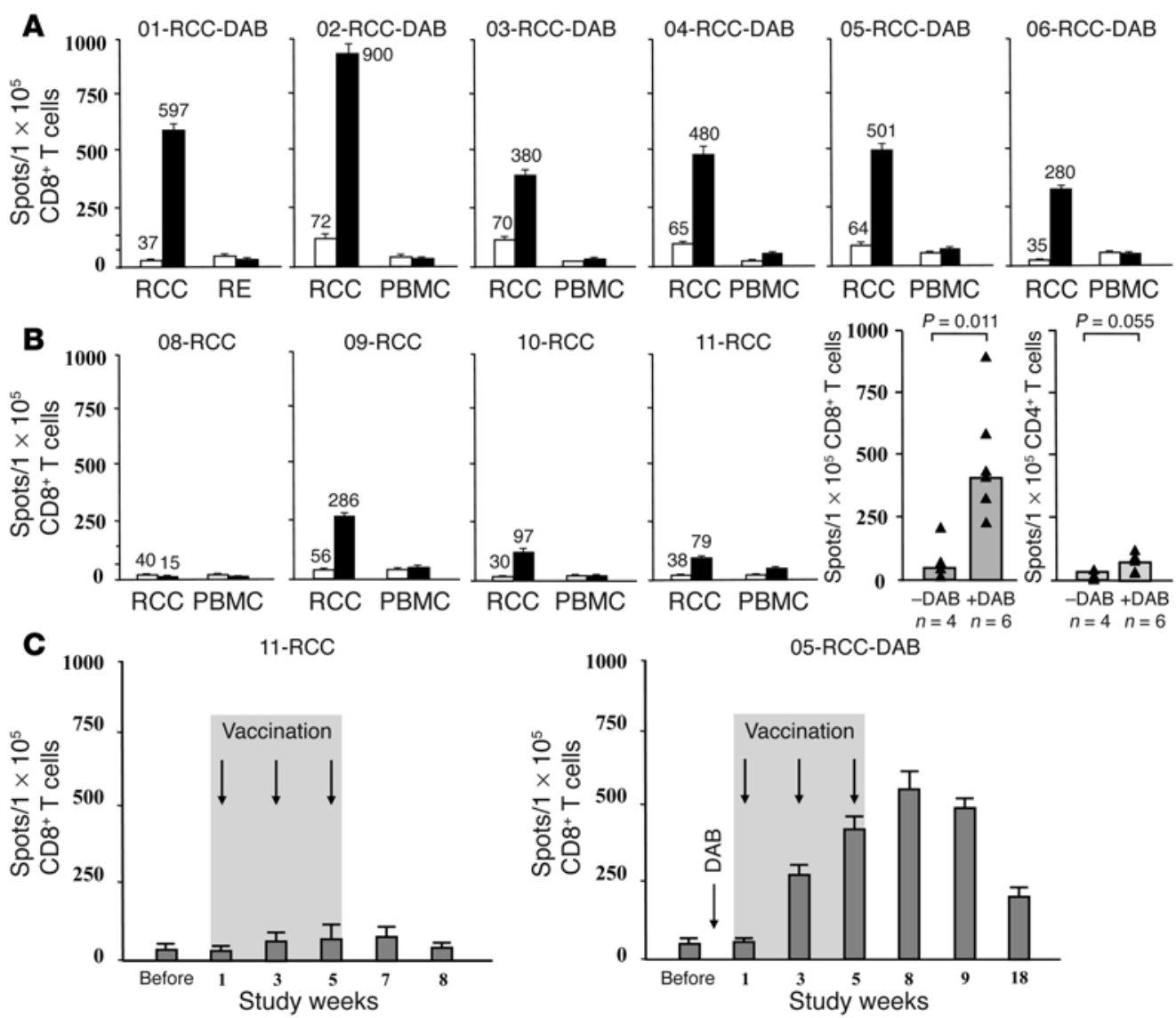

Figure 5

In vivo induction of tumor-specific $T$ cell responses. (A) $C D 8^{+}$and $C D 4^{+} T$ cells were isolated from prevaccination (white bars) and postvaccination (black bars) PBMCs of patients treated with $\mathrm{DAB}_{389} \mathrm{IL}-2$ and RCC RNA-transfected DCs. For vaccination, 3 doses of $1 \times 10^{7}$ cells injected intradermally every other week were administered. Isolated $\mathrm{CD}^{+}$and $\mathrm{CD} 4^{+} \mathrm{T}$ cells were stimulated for 18 hours with tumor RNA-transfected DCs, RE, or PBMC RNA-transfected DCs (controls). Visible spots were enumerated, and antigen-specific $T$ cell frequencies were expressed as the number of spots forming cells per $1 \times 10^{5} \mathrm{~T}$ cells. (B) Left panels: stimulation of tumor-specific CD8 ${ }^{+}$in 4 subjects treated with tumor RNA-transfected DCs alone. Right panels: summary of $\mathrm{CD}^{+}$and $\mathrm{CD} 4+\mathrm{T}$ cell responses from 4 subjects receiving immunization alone (-DAB) or from 7 patients treated with combined therapy (+DAB). Bars indicate the median value of all subjects analyzed. Filled triangles represent $\mathrm{T}$ cell frequencies of individual patients. (C) Temporal evolution of tumor-specific CD8 $8^{+} \mathrm{T}$ cells after vaccination. IFN- $\gamma$ ELISPOT analyses on sorted $\mathrm{CD} 8^{+} \mathrm{T}$ cells were performed as described in $\mathbf{A}$. Frequencies of tumor-specific T cells prior to, during, and after immunization are presented for 2 patients who received 3 vaccinations with tumor mRNA-transfected DCs alone (11-RCC) or were treated with $\mathrm{DAB}_{389} \mathrm{IL}-2$ (01-RCC-DAB) followed by vaccination.

$\mathrm{DAB}_{389} \mathrm{IL}-2-$ mediated Treg depletion may induce toxicity within the memory $\mathrm{T}$ cell pool (CD4 $\left.{ }^{+} / \mathrm{CD} 25^{\text {int }}\right)$, a series of experiments was performed analyzing $\mathrm{CD}^{+} / \mathrm{CD} 25^{\text {int }} \mathrm{T}$ cell function prior to and 4 days after $\mathrm{DAB}_{389} \mathrm{IL}-2$ administration. First, IFN- $\gamma$ ELISPOT analyses were performed on sorted $\mathrm{CD} 4^{+} / \mathrm{CD} 25^{\text {neg }}, \mathrm{CD} 4^{+} / \mathrm{CD} 25^{\text {int }}$, and $\mathrm{CD}^{+} / \mathrm{CD} 25^{\text {high }} \mathrm{T}$ cell subsets using tetanus toxoid or CMV lysatepulsed DCs as stimulators. As shown in Figure 4B, only $\mathrm{CD}^{+} /$ $\mathrm{CD} 25^{\text {int }}$ memory $\mathrm{T}$ cells were capable of stimulating $\mathrm{T}$ cell responses against tetanus or CMV antigens while naive (CD4 $\left.4^{+} / \mathrm{CD} 25^{\text {neg }}\right)$ and $\mathrm{CD}^{+} / \mathrm{CD} 25^{\text {high }} \mathrm{T}$ cells failed to stimulate $\mathrm{T}$ cell responses of a significant magnitude. In a second set of experiments, the frequency of IFN- $\gamma$ secreting $T$ cells was analyzed using $\mathrm{CD}^{+}$ (Figure $4 \mathrm{C}$ ) and $\mathrm{CD}^{+}$responder $\mathrm{T}$ cells isolated from human PBMCs (Figure 4D) prior to and 4 days after $\mathrm{DAB}_{389} \mathrm{IL}-2$ admin-
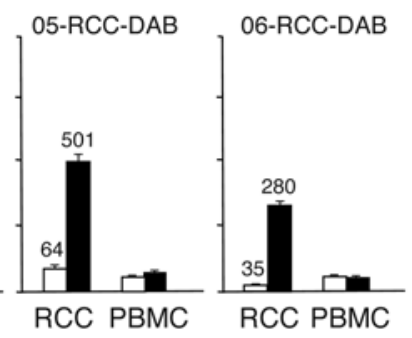

istration (DAB) and 2 weeks after 3 vaccination cycles. Over the entire treatment cycle, no differences were observed in the absolute number of T cells with specificity against PBMC RNAtransfected DCs, influenza virus matrix protein 1 (fluM1) mRNA-transfected DCs, CMV lysate-loaded DCs, or tetanus toxoid-loaded DCs. Furthermore, antigen-specific proliferation assays (Figure $4 \mathrm{E}$ ) revealed strong reactivities against renal tumor antigens and unchanged reactivities against the prototype recall antigens fluM1/ tetanus toxoid.

Cumulatively, the experiments shown in Figures 3 and 4 demonstrate that administration of a single dose of $\mathrm{DAB}_{389} \mathrm{IL}-2$ resulted in significantly reduced numbers of Tregs in the peripheral blood of RCC patients (Figure 3, A and B) and in significant abrogation of Treg-mediated suppressive activity (Figure 3C). Our data further suggest that $\mathrm{DAB}_{389} \mathrm{IL}-2$-mediated toxicities against other hematopoietic cells expressing CD25 are unlikely and that lymphopenia-induced $\mathrm{T}$ cell proliferation (27) may not represent a significant issue in a vaccination setting.

In vivo stimulation of tumorspecific $T$ cell responses. In order to determine whether $\mathrm{DAB}_{389} \mathrm{IL}-2$-mediated Treg depletion is capable of augmenting vaccine-induced $\mathrm{CD}^{+}$and $\mathrm{CD} 4^{+} \mathrm{T}$ cell responses in cancer patients, IFN- $\gamma$ ELISPOT analyses were performed to determine the frequencies of vaccine-induced, tumor-specific $T$ cells from PBMC samples collected before and 2 weeks after the third vaccination. $\mathrm{CD}^{+}$and $\mathrm{CD} 4^{+} \mathrm{T}$ cells were isolated from preand post-vaccination PBMCs and cultured overnight with tumor RNA-transfected DC targets. As controls, autologous PBMC RNA and/or autologous benign RE-derived RNA-transfected DCs were used for short-term antigenic stimulation. As shown in Figure 5, A and B, only background levels of RE- or PBMC-specific T cells were observed prior to or after vaccination. Also, tumorspecific $T$ cell responses did not significantly increase in independently evaluated subjects after treatment with $\mathrm{DAB}_{389} \mathrm{IL}-2$ alone over a period of 28 days (data not shown). In contrast, all 
A
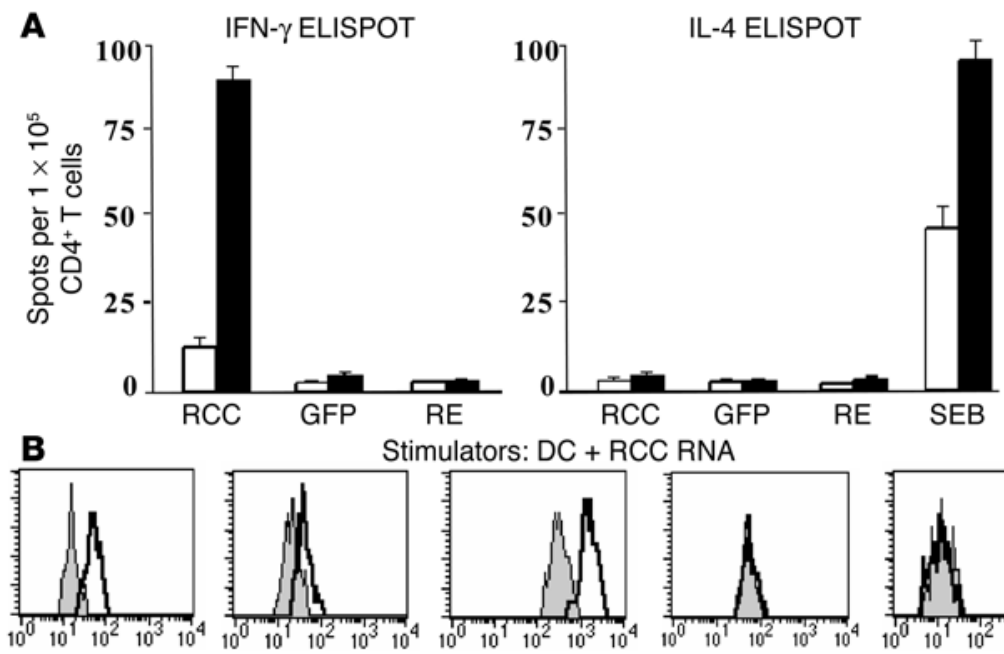

Stim
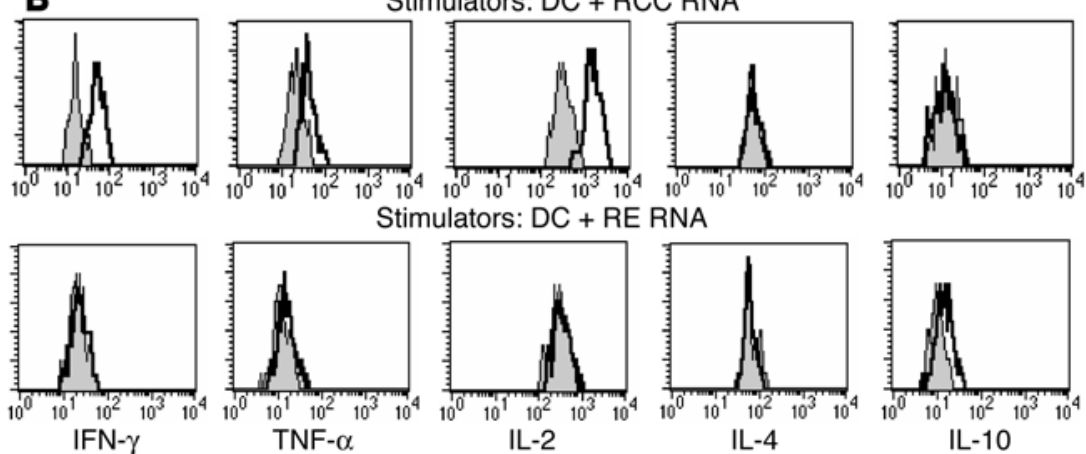

\section{Figure 6}

In vivo induction and cytokine profile of RCC-specific CD4 ${ }^{+} \mathrm{T}$ cell responses. (A) $\mathrm{CD} 4{ }^{+} \mathrm{T}$ cells were isolated from pre- (white bars) and post-vaccination (black bars) PBMC samples of 3 study subjects (representative data from patient RCC-01-DAB are shown) who received $D A_{389} \mathrm{~L}-2(18 \mu \mathrm{g} / \mathrm{kg})$ followed by vaccination with RCC RNA-transfected DCs ( 2 cycles of $1 \times 10^{7}$ cells per treatment). Cells were stimulated for 18 hours with autologous PBMC RNA-, RE RNA-, or RCC RNA-transfected DCs. IFN- $\gamma$ (left panel) or IL-4-expressing T cells (right panel) were enumerated using an automated ELISPOT reader, and antigen-specific $T$ cell frequencies were expressed as the number of spot-forming cells per $1 \times 10^{5} \mathrm{CD}^{+} \mathrm{T}$ cells. Staphylococcal enterotoxin B (SEB) at a concentration of $10 \mu \mathrm{g} / \mathrm{ml}$ was used as a positive control in the IL-4 ELISPOT assays (right panel). (B) The cytokine expression profile of CD4+ $\mathrm{T}$ cells prior to (gray) and after (white) vaccination was measured after overnight (18 hours) stimulation with RCC (DC+RCC) or RE RNA-transfected DCs (DC+RE) using human Th1/Th2 cytometric bead arrays. Culture supernatants were used to determine expression of the Th- 1 cytokines IFN- $\gamma$, TNF- $\alpha$, and IL-2 as well as the Th- 2 type cytokines IL- 4 and IL- 10 . but 1 (08-RCC) patient immunized with tumor RNA-transfected DCs exhibited significant increases in tumor-specific $\mathrm{CD}^{+}$ and $\mathrm{CD}^{+} \mathrm{T}$ cell frequencies after vaccination (Figure $5 \mathrm{~B}$ and Table 1). A 2.7-fold median increase (range 0 to 5.1) of tumorspecific $\mathrm{CD}^{+} \mathrm{T}$ cells and a 2.0 -fold median increase in tumorspecific $\mathrm{CD}^{+} \mathrm{T}$ cells (range 1.0 to 4.5 ) was observed in the subjects receiving vaccination alone (Table 1 ). Although there was significant patient-to-patient variability in the magnitude of $\mathrm{T}$ cell responses measured in each patient, vaccination after Treg depletion stimulated significantly higher numbers of tumorspecific $\mathrm{CD}^{+} \mathrm{T}$ cells in RCC patients receiving $\mathrm{DAB}_{389} \mathrm{IL}-2$ plus RCC RNA-transfected DCs, when compared with RCC patients receiving vaccination alone $(P=0.011)$. Moreover, there was a trend toward improved $\mathrm{CD}^{+} \mathrm{T}$ cell responses $(P=0.055)$ in RCC patients treated with combined therapy (Figure 5B). A 7.9-fold median increase in the number of tumor-specific $\mathrm{CD}^{+} \mathrm{T}$ cells (range 5.4 to 16.2 ) and a 7.2 -fold median increase in $\mathrm{CD}^{+} \mathrm{T}$ cells (range 2.2 to 31.0 ) was detected in the 6 RCC patients receiving $\mathrm{DAB}_{389} \mathrm{IL}-2$ plus vaccination with RCC RNA-transfected DCs. The absolute $\mathrm{CD}^{+} \mathrm{T}$ cell frequencies achieved with combined therapy were remarkably high with up to $0.90 \%$ of $\mathrm{CD}^{+} \mathrm{T}$ cells exhibiting tumor specificity after 3 vaccinations. In order to evaluate the temporal evolution of the $\mathrm{T}$ cell response stimulated by vaccination with or without $\mathrm{DAB}_{386} \mathrm{IL}-2$ therapy, longitudinal monitoring of vaccine-induced $\mathrm{CD}^{+} \mathrm{T}$ cell responses was performed using IFN- $\gamma$ ELISPOT in 2 subjects from whom sufficient numbers of cells were available for analysis (11-RCC and 05-RCC-DAB). DAB ${ }_{389}$ IL-2-mediated Treg depletion followed by vaccination resulted in a significantly enhanced and also prolonged $\mathrm{CD}^{+} \mathrm{T}$ cell response when compared with the subject receiving vaccination alone. As demonstrated recently (26), the vaccine-induced and tumor-specific CTL response surged over the entire treatment course and peaked approximately 2 weeks after the third and final dose (Figure 5C).
In additional experiments, the cytokine secretion profiles by vaccine-induced and tumor-specific $\mathrm{CD}^{+} \mathrm{T}$ cells were analyzed after combined $\mathrm{DAB}_{389} \mathrm{IL}-2$ and active immunotherapy (Figure 6, A and B). PBMCs were collected from 3 study subjects at baseline and 2 weeks after the final vaccination, and $\mathrm{CD}^{+} \mathrm{T}$ cells were isolated by magnetic bead sorting. $\mathrm{CD}^{+} \mathrm{T}$ cells were restimulated for 18 hours with renal tumor RNA-transfected DCs and analyzed for IFN- $\gamma$ and IL- 4 secretion using ELISPOT analysis. As control targets, GFP mRNA-, RE RNA-transfected DCs, and staphylococcal enterotoxin B (SEB) were used. As shown in Figure 6A, vaccination after Treg depletion resulted in significant stimulation of IFN- $\gamma$ but not IL-4-secreting renal tumor-specific $\mathrm{CD}^{+}{ }^{+} \mathrm{T}$ cells while no stimulation against GFP or RE-expressing targets was noted. In addition, human Th1/ Th2 flow cytometry-based bead arrays (Figure 6B) confirmed secretion of the Th-1 type cytokines IL-2 (increase from 680 to $1270 \mathrm{pg} / \mathrm{ml}), \operatorname{IFN}-\gamma(160$ to $270 \mathrm{pg} / \mathrm{ml})$, and TNF- $\alpha$ (34 to $59 \mathrm{pg} / \mathrm{ml}$ ) but not Th-2 type cytokines (IL-10 and IL-4) by vaccine-induced $\mathrm{CD}^{+} \mathrm{T}$ cells 18 hours after stimulation with RCC RNA-transfected DCs. This effect was not seen when RE RNAtransfected DCs were used as stimulators. These data further suggest that the vaccine-induced tumor-specific $\mathrm{T}$ cell response is directed against tumor-associated antigens but not gene products expressed by normal RE.

In conclusion, we show that Treg depletion using the diphtheria fusion protein $\mathrm{DAB}_{389} \mathrm{IL}-2$ is capable of enhancing a vaccineinduced $\mathrm{T}$ cell response in patients with advanced RCC. Although only a limited number of patients were studied in this clinical trial, an up to 16 -fold increase in tumor-specific CTL frequencies could be measured in subjects receiving combined treatment when compared with individuals receiving vaccination alone. The vaccine-induced $\mathrm{T}$ cell frequencies achieved without Treg depletion were similar to those observed in a prior study in which immature tumor RNA-transfected DCs were used for vaccination (1). 


\section{Discussion}

The objective of this study was to enhance the immunostimulatory efficacy of RNA-transfected DC vaccines by selectively eliminating $\mathrm{CD}^{+} / \mathrm{CD} 25^{\text {high }}$ Tregs in metastatic RCC patients. For Treg depletion, we used the recombinant fusion protein denileukin diftitox $\left(\mathrm{DAB}_{389} \mathrm{IL}-2\right)(20)$ in a human vaccination setting. We show that human $\mathrm{CD} 4{ }^{+} \mathrm{CD} 25^{\text {high }}$ Tregs can be eliminated using a single dose of $\mathrm{DAB}_{389} \mathrm{IL}-2$ without apparent bystander toxicity and without having an impact on the function of other cells expressing CD25. However, DAB ${ }_{389} \mathrm{IL}-2$ also abrogated DCmediated activation of $\mathrm{T}$ cells in vitro, suggesting that the applicability of this reagent should be restricted to a prevaccination setting (Figure 2C). These preclinical results provided important information regarding the design of our clinical study, in which $\mathrm{DAB}_{389} \mathrm{IL}-2$ was administered to RCC patients 4 days prior to DCbased vaccination. This time interval was chosen since, unlike antibodies, $\mathrm{DAB}_{389} \mathrm{IL}-2$ is characterized by a short duration of action, with a half-life of approximately 60 minutes, thereby minimizing the possibility of interfering with the ongoing vaccine-induced $T$ cell response.

In this study, $\mathrm{DAB}_{389} \mathrm{IL}-2$ profoundly reduced the number of Tregs present in the peripheral blood of RCC patients, reduced levels of peripheral blood-derived FoxP 3 transcripts, and abrogated Treg-mediated immunosuppressive activity in vivo. Moreover, significantly higher frequencies of tumor-specific $\mathrm{CD}^{+} \mathrm{T}$ cells could be measured in patients treated with combined $\mathrm{DAB}_{389} \mathrm{IL}-2$ and vaccination when compared with subjects receiving the vaccine alone. Also, there was a trend toward an improved $\mathrm{CD} 4^{+} \mathrm{T}$ cell response after combined therapy. Cumulatively, these data provide several independent lines of evidence that Tregs were depleted in the peripheral blood of RCC patients by using a single dose of the fusion protein $\mathrm{DAB}_{389} \mathrm{IL}-2$.

The $\mathrm{T}$ cell frequencies achieved after Treg depletion and 3 vaccination cycles were remarkably high with up to $0.90 \%$ of all $\mathrm{CD}^{+} \mathrm{T}$ cells demonstrating tumor specificity. No clear correlation between the efficacy of Treg depletion and the magnitude of the vaccine-induced $T$ cell response was observed. Also, serum diphtheria titers did not appear to have an impact on vaccine efficacy (11). The present study further suggests that the degree of Treg depletion achieved using a single dose of $18 \mu \mathrm{g} / \mathrm{kg}$ may be quite variable and that Treg depletion was transient, with most cells returning after 2 months. However, it should be pointed out that the exact enumeration of Tregs in a vaccination setting is complicated by the fact that $\mathrm{CD}^{+} \mathrm{T}$ cells with negative or intermediate expression levels of CD25 may upregulate expression of CD25 in response to antigenic stimulation, thereby biasing results towards increased detection of Tregs. Our preclinical studies also suggest that the Treg strategy may be geared toward the improvement of $\mathrm{T}$ cell responses against relatively weak self antigens such as hTERT or MART-1 antigens but not against immunodominant peptide-derived antigens (Figure 2D). Accordingly, other studies have recently shown that Tregs effectively suppress the physiologic activation of autoreactive $T$ cells associated with low strength of the antigenic signal while $T$ cells activated with high antigenic signal strength were refractory to this mechanism of suppression (25). Although in this study, the concept of Treg elimination has been employed in context with RNA-transfected DC-based vaccination, this strategy could potentially be applied to many immune-based approaches of active and passive immunotherapy as well as to classical adju- vants. The information gained from this study will serve as a baseline for further clinical investigation to better define the full potential of this strategy in ultimately achieving antitumor immunity with clinical impact. For such studies it will be critical to collect precise information on Treg depletion and vaccineinduced $T$ cell response and, ultimately, address the clinical efficacy of such strategy in cancer patients.

\section{Methods}

Clinical trial design and patient eligibility. Treatment of patients was performed following written informed consent as part of a protocol approved by an Institutional Review Board and the FDA. Patients with histologically confirmed metastatic RCC were eligible for this study. One patient with disseminated OVA was included and treated on a compassionate basis. All patients were required to have adequate hepatic, renal, and neurological function, a life expectancy of more than 6 months, and a Karnofsky performance status of greater than or equal to $70 \%$. Patients had to have recovered from all toxicities related to any prior therapy and not received any chemotherapy, radiation therapy, or immunotherapy for at least 6 weeks prior to study entry. Excluded from the study were patients with CNS metastases, with a history of autoimmune disease, and with serious intercurrent chronic or acute illnesses. Patients on immunosuppressive agents were also excluded. Eligible subjects were randomized with equal probability to receive either a single dose of $\mathrm{DAB}_{389} \mathrm{IL}-2(18 \mu \mathrm{g} / \mathrm{kg})$ followed by vaccination with tumor RNA-transfected DCs or vaccination alone. All subjects received 3 intradermal injections of tumor RNA-transfected DCs. The injections were given intradermally at biweekly intervals and consisted of $1 \times 10^{7}$ cells suspended in $200 \mu \mathrm{l} 0.9 \%$ sodium chloride at each vaccination. Following treatment, subjects were evaluated for clinical toxicity and immunological and clinical responses. Due to regulatory restrictions and, in some subjects, limited access to tumor tissue, no tumor biopsies were performed.

$D A B_{389} I L-2$ and vaccine preparation. DAB ${ }_{389}$ IL-2 (ONTAK; Ligand Pharmaceuticals) was provided as a frozen, sterile solution formulated in citrate buffer in $2 \mathrm{ml}$ single-use vials at a concentration of $150 \mu \mathrm{g} / \mathrm{ml}$. After thawing, $\mathrm{DAB}_{389} \mathrm{IL}-2$ was diluted with sterile normal saline to a final concentration of $15 \mu \mathrm{g} / \mathrm{ml}$ and delivered by intravenous infusion over a 30 -minute period. Patients were permitted to receive acetaminophen $(600 \mathrm{mg})$ and antihistamines 30 to 60 minutes prior to infusion. For DC culture, a concentrated leukocyte fraction was harvested by leukapheresis. PBMCs were isolated from the leukapheresis product by density gradient centrifugation (Histopaque; Sigma-Aldrich). The semiadherent cell fraction was used for DC culture in serum-free X-VIVO 15 medium (Cambrex Corp.) supplemented with recombinant human IL-4 (500 U/ml) (R\&D Systems) and recombinant human GM-CSF (rhGM-CSF) (800 U/ml) (Immunex Corp.). After 7 days, immature DCs were harvested and transfected with total RNA extracted from tumor tissues histologically classified as clear cell carcinoma. Control RNA used for immunological monitoring studies was isolated from autologous benign renal tissues (RE) or from PBMCs. Transfection of immature DCs was carried out by electroporation. DCs were washed in PBS and resuspended at a concentration of $4 \times 10^{7}$ cells $/ \mathrm{ml}$ in ViaSpan (Barr Laboratories). Cells were then coincubated for 5 minutes with $5 \mu \mathrm{g}$ RNA per $1 \times 10^{6}$ cells and electroporated in $0.4 \mathrm{~cm}$ cuvettes via exponential decay delivery at $300 \mathrm{~V}$ and $150 \mu \mathrm{F}$ (Gene Pulser II; Bio-Rad). After electroporation, cells were resuspended in X-VIVO 15 medium and matured for 20 hours in the presence of $10 \mathrm{ng} / \mathrm{ml} \mathrm{TNF}-\alpha, 10 \mathrm{ng} / \mathrm{ml} \mathrm{IL-} 1 \beta$, $150 \mathrm{ng} / \mathrm{ml} \mathrm{IL}-6$ (R\&D Systems), and $1 \mu \mathrm{g} / \mathrm{ml}$ prostaglandin $\mathrm{E}_{2}\left(\mathrm{PGE}_{2}\right)$ (Cayman Chemical Co.). Prior to administration, cells were characterized to ensure that they met the typical phenotype of fully mature DCs: Lin ${ }^{\text {neg, }}$ HLA class I and II ${ }^{\text {high }}$, CD86 $6^{\text {high }}$, and CD83 $3^{\text {high }}$. 
Evaluation of immune status. IFN- $\gamma$ and IL-4 ELISPOT analyses were performed using PBMCs obtained prior to, during, and after vaccination. PBMCs were cultured overnight in complete RPMI 1640 medium. $\mathrm{CD}^{+}$and $\mathrm{CD}^{+} \mathrm{T}$ cells were isolated from PBMCs by negative depletion (Miltenyi Biotec). After blocking, $1 \times 10^{5} \mathrm{~T}$ cells and $1 \times 10^{4}$ RNA-transfected DCs were added to each well of 96-well nitrocellulose plates (Multiscreen-IP; Millipore) precoated with $2 \mu \mathrm{g} / \mathrm{ml} \mathrm{IFN-} \gamma$ capture antibody (Pierce Biotechonology Inc.) or with IL-4 capture antibody (BD Biosciences - Pharmingen). Plates were incubated for 20 hours at $37^{\circ} \mathrm{C}$, and biotinylated IFN- $\gamma$ detection antibody (Pierce Biotechonology Inc.) or biotinylated IL-4 antibody (BD Biosciences - Pharmingen) was added to each well. Cells were then incubated for an additional 2 hours at room temperature, then with streptavidin-alkaline phosphatase $(1 \mu \mathrm{g} / \mathrm{ml}$; Sigma-Aldrich); plates were developed with substrate (KPL). After washing, spots were counted using an automated ELISPOT reader (Zeiss). CTL assays were performed by coculturing RNA-transfected DCs with autologous PBMCs. Cells were restimulated once, and IL-2 (20 units/ml) was added after 5 days and every other day thereafter. After 12 days of culture, effector cells were harvested. Target cells were labeled with $100 \mu \mathrm{Ci}$ of $\mathrm{Na}_{2}\left[{ }^{51} \mathrm{CrO}_{4}\right]$ (PerkinElmer) in $200 \mu \mathrm{l}$ of complete RPMI 1640 for 1 hour at $37^{\circ} \mathrm{C}$ in $5 \% \mathrm{CO}_{2}$, and ${ }^{51} \mathrm{Cr}$-labeled target cells were incubated in complete RPMI 1640 medium with effector cells for 5 hours at $37^{\circ} \mathrm{C}$. Then $50 \mu \mathrm{l}$ of supernatant was harvested, and release of ${ }^{51} \mathrm{Cr}$ was measured with a scintillation counter. For proliferation assays, purified $\mathrm{CD}^{+} \mathrm{T}$ cells were seeded into round-bottomed microplates in the presence of mRNA-transfected DCs. T cells alone were used as the background control. After 4 days, $1 \mu \mathrm{Ci}$ of $\left[\right.$ methyl $\left.^{-3} \mathrm{H}\right]$ thymidine (PerkinElmer) was added to each well for an additional 16 hours. Incorporation of thymidine was determined using a liquid scintillation counter. Cytotoxicity of $\mathrm{DAB}_{389} \mathrm{IL}-2$ was determined in MTT assays. After 6 hours incubation with varying concentrations of $\mathrm{DAB}_{389} \mathrm{IL}-2$, cells were seeded in 96-well plates at a density of $5 \times 10^{3}$ cells/well. After 48 hours of incubation, $20 \mu \mathrm{l}$ MTT from a $5 \mathrm{mg} / \mathrm{ml}$ stock was added. After 4 hours, the formazan crystals were solubilized by adding $100 \mu \mathrm{l}$ isopropanol/0.1 M hydrochloric acid. The absorbance of the formazan product was measured on an ELISA plate reader at $570 \mathrm{~nm}$. Cytokine secretion by vaccine-induced $\mathrm{CD} 4^{+} \mathrm{T}$ cells was measured using the human Th-1/Th-2 cytokine kit (Cytokine Bead Array; BD Biosciences - Pharmingen) according to the manufacturer's instructions. Isolated $\mathrm{CD}^{+} \mathrm{T}$ cells were restimulated overnight with RNA-transfected DCs at a ratio of 10:1.

FACS analysis. Four-color FACS analyses were performed using the following antibodies: anti-CD4 FITC, anti-CD45RO, anti-CD45RA (CALTAG Laboratories), anti-CD25 PE (BD Biosciences - Pharmingen), and antiGITR (R\&D Systems) as well as isotypic controls (CALTAG Laboratories). Sorting of $\mathrm{CD}^{+} / \mathrm{CD} 25^{\text {neg }}, \mathrm{CD} 4^{+} / \mathrm{CD} 25^{\text {int }}$ and $\mathrm{CD} 4^{+} / \mathrm{CD} 25^{\text {high }} \mathrm{T}$ cells was performed using a BD FACSAria cell sorter after antibody labeling. For intracellular detection of FoxP3, cells were permeabilized with $30 \mu \mathrm{g} / \mathrm{ml}$ digitonin for 45 minutes at $4{ }^{\circ} \mathrm{C}$. Subsequently, cells were stained with
anti-FoxP3 antibody (Abcam), and R-phycoerythrin anti-goat IgG in the presence of $10 \mu \mathrm{g} / \mathrm{ml}$ digitonin for 30 minutes at $4^{\circ} \mathrm{C}$. Following staining, cells were fixed and analyzed by FACS. For intracellular CTLA- 4 detection, T cells were permeabilized, fixed, and stained with biotinylated anti-CD152 (BD Biosciences - Pharmingen) followed by APC-strepavidin (BD Biosciences - Pharmingen). A total of $1 \times 10^{6}$ cells were suspended in staining buffer (PBS with $1 \%$ FCS, 2 mM EDTA, and $0.1 \%$ sodium azide) and incubated for 20 minutes at $4^{\circ} \mathrm{C}$ with the antibody.

Treg functional evaluation. The suppressive activity of Tregs isolated from PBMCs of study subjects prior to and 4 days after $\mathrm{DAB}_{386} \mathrm{IL}-2$ administration was analyzed, as described previously (28). $\mathrm{CD} 4^{+} / \mathrm{CD} 25^{+} \mathrm{T}$ cells were isolated from the PBMCs of study subjects using magnetic bead separation techniques. Cells were washed with PBS, resuspended in complete RPMI 1640 medium, and placed into 96-well round bottom plates precoated with anti-CD3/CD28 antibodies ( $0.4 \mu \mathrm{g} /$ well) (CALTAG Laboratories). $\mathrm{CD}^{+} / \mathrm{CD} 25^{-}$cells were plated at $2.0 \times 10^{4} /$ well alone or in combination with $\mathrm{CD}^{+} / \mathrm{CD}^{2} 5^{+}$cells in triplicate wells at a ratio of $1: 2\left(\mathrm{CD} 4^{+} / \mathrm{CD} 25^{-}\right.$: $\left.\mathrm{CD} 4^{+} \mathrm{CD} 25^{+}\right)$. On day $5,1 \mu \mathrm{Ci}$ of ${ }^{3} \mathrm{H}$ thymidine was added for the final 16 hours of the cultures. Cells were then harvested on glass fiber filters and assessed for uptake of radiolabeled thymidine.

Detection of FoxP3 transcripts. Details of real-time PCR-based quantification of $\beta$-actin transcripts were previously provided by Heiser et al. (2). FoxP3 mRNA transcripts were quantified using the Hs00203958_ml TaqMan gene expression assay (Applied Biosystems) according to the protocol provided by the manufacturer. A plasmid containing the full-length FoxP3 insert was used to generate standard curves.

Statistics. T cell analysis before and after treatment was performed by IFN- $\gamma$ ELISPOT on all patients who completed immunotherapy. Increases of antigen-specific $\mathrm{CD}^{+}$and $\mathrm{CD}^{+}{ }^{+} \mathrm{T}$ cells after vaccination were compared using the Wilcoxon matched-pairs signed rank test, analyzing the null hypothesis that the rates of change in $\mathrm{T}$ cell response were equivalent prior to and after therapy. A 2 -sided $P$ value of less than 0.05 was considered statistically significant.

\section{Acknowledgments}

This work was supported in part by NIH grants R21-CA098446-02 (National Cancer Institute) and M01-RR-30 (National Center for Research Resources, General Clinical Research Centers Program). We would like to thank Ligand Pharmaceuticals for provision of the fusion protein for the clinical study.

Received for publication June 13, 2005, and accepted in revised form October 4, 2005.

Address correspondence to: Johannes Vieweg, Duke University Medical Center, MSRB, Suite 455, DUMC Box 2626, Durham, North Carolina 27710, USA. Phone: (919) 684-9949; Fax: (919) 681-7414; E-mail: j.vieweg@duke.edu.
1. Su, Z., et al. 2003. Immunological and clinical responses in metastatic renal cancer patients vaccinated with tumor RNA-transfected dendritic cells. Cancer Res. 63:2127-2133.

2. Heiser, A., et al. 2002. Autologous dendritic cells transfected with prostate-specific antigen RNA stimulate CTL responses against metastatic prostate tumors. J. Clin. Invest. 109:409-417. doi:10.1172/JCI200214364.

3. Shevach, E.M. 2001. Certified professionals: CD4(+)CD25(+) suppressor T cells. J. Exp. Med. 193:F41-F46.

4. Jonuleit, H., Schmitt, E., Schuler, G., Knop, J., and Enk, A.H. 2000. Induction of interleukin 10-pro- ducing, nonproliferating CD4(+) T cells with regulatory properties by repetitive stimulation with allogeneic immature human dendritic cells. J. Exp. Med. 192:1213-1222.

5. Read, S., and Powrie, F. 2001. CD4(+) regulatory T cells. Curr. Opin. Immunol. 13:644-649.

6. Woo, E.Y., et al. 2002. Cutting edge: regulatory $\mathrm{T}$ cells from lung cancer patients directly inhibit autologous $\mathrm{T}$ cell proliferation. J. Immunol. 168:4272-4276.

7. Curiel, T.J., et al. 2004. Specific recruitment of regulatory $\mathrm{T}$ cells in ovarian carcinoma fosters immune privilege and predicts reduced survival. Nat. Med. 10:942-949.
8. Shimizu, J., Yamazaki, S., and Sakaguchi, S. 1999. Induction of tumor immunity by removing CD25+CD4+ T cells: a common basis between tumor immunity and autoimmunity. J. Immunol. 163:5211-5218.

9. Onizuka, S., et al. 1999. Tumor rejection by in vivo administration of anti-CD25 (interleukin-2 receptor alpha) monoclonal antibody. Cancer Res. 59:3128-3133.

10. Sutmuller, R.P., et al. 2001. Synergism of cytotoxic $T$ lymphocyte-associated antigen 4 blockade and depletion of CD25(+) regulatory $\mathrm{T}$ cells in antitumor therapy reveals alternative pathways for suppression of autoreactive cytotoxic $\mathrm{T}$ lymphocyte 
responses. J. Exp. Med. 194:823-832.

11. Frankel, A.E., Powell, B.L., and Lilly, M.B. 2002. Diphtheria toxin conjugate therapy of cancer. Cancer Chemother. Biol. Response Modif. 20:301-313.

12. Takahashi, T., et al. 1998. Immunologic self-tolerance maintained by $\mathrm{CD} 25+\mathrm{CD} 4+$ naturally anergic and suppressive $\mathrm{T}$ cells: induction of autoimmune disease by breaking their anergic/suppressive state. Int. Immunol. 10:1969-1980.

13. Waldmann, T.A. 1991. The interleukin-2 receptor. J. Biol. Chem. 266:2681-2684.

14. Wing, K., Ekmark, A., Karlsson, H., Rudin, A., and Suri-Payer, E. 2002. Characterization of human CD25+ CD4+ T cells in thymus, cord and adult blood. Immunology. 106:190-199.

15. Read, S., et al. 1998. CD38+ CD45RB(low) CD4+ T cells: a population of $\mathrm{T}$ cells with immune regulatory activities in vitro. Eur. J. Immunol. 28:3435-3447.

16. Thornton, A.M., and Shevach, E.M. 2000. Suppressor effector function of CD4+CD25+ immunoregulatory $\mathrm{T}$ cells is antigen nonspecific. J. Immunol. 164:183-190.
17. Morgan, M.E., et al. 2005. Expression of FOXP3 mRNA is not confined to $\mathrm{CD} 4+\mathrm{CD} 25+\mathrm{T}$ regulatory cells in humans. Hum. Immunol. 66:13-20.

18. Woo, E.Y., et al. 2001. Regulatory CD4(+)CD25(+) $T$ cells in tumors from patients with early-stage non-small cell lung cancer and late-stage ovarian cancer. Cancer Res. 61:4766-4772.

19. Rosolen, A., et al. 1989. Expression of interleukin-2 receptor beta subunit in hematopoietic malignancies. Blood. 73:1968-1972.

20. Olsen, E., et al. 2001. Pivotal phase III trial of two dose levels of denileukin diftitox for the treatment of cutaneous T-cell lymphoma. J. Clin. Oncol. 19:376-388.

21. Jonuleit, H., Schmitt, E., Steinbrink, K., and Enk, A.H. 2001. Dendritic cells as a tool to induce anergic and regulatory T cells. Trends Immunol. 22:394-400.

22. Heiser, A., et al. 2000. Human dendritic cells transfected with RNA encoding prostate specific antigen stimulate prostate specific CTL responses in vitro. J. Immunol. 164:5508-5514.

23. Heiser, A., et al. 2001. Human dendritic cells trans- fected with renal tumor RNA stimulate polyclonal Tcell responses against antigens expressed by primary and metastatic tumors. Cancer Res. 61:3388-3393.

24. Heiser, A., et al. 2001. Induction of polyclonal prostate cancer specific cytotoxic T lymphocytes using dendritic cells transfected with amplified tumor RNA. J. Immunol. 166:2953-2960.

25. Baecher-Allan, C., Viglietta, V., and Hafler, D.A. 2002. Inhibition of human CD4(+)CD25(+high) regulatory $\mathrm{T}$ cell function. J. Immunol. 169:6210-6217.

26. Su, Z., et al. 2005. Telomerase mRNA-transfected dendritic cells stimulate antigen-specific CD8+ and CD4+ $\mathrm{T}$ cell responses in patients with metastatic prostate cancer. J. Immunol. 174:3798-3807.

27. Goldrath, A.W., Luckey, C.J., Park, R., Benoist, C., and Mathis, D. 2004. The molecular program induced in $\mathrm{T}$ cells undergoing homeostatic proliferation. Proc. Natl. Acad. Sci. U. S. A. 101:16885-16890.

28. Tsaknaridis, L., et al. 2003. Functional assay for human $\mathrm{CD} 4+\mathrm{CD} 25+$ Treg cells reveals an agedependent loss of suppressive activity. J. Neurosci. Res. 74:296-308. 